\title{
Osmotic induction marking with Alizarin Red S on juveniles of pejerrey, Odontesthes bonariensis (Atherinopsidae)
}

\author{
Daniela Campanella ${ }^{1}$, Ángela Gárriz ${ }^{1}$, Darío C. Colautti ${ }^{2}$, Gustavo M. Somoza ${ }^{1}$ and \\ Leandro A. Miranda ${ }^{1}$
}

Juveniles of pejerrey, Odontesthes bonariensis, were exposed to $0.1 \%$ Alizarin Red S (ARS) alone or with a previous immersion in $2.2 \%$ saline solution (Osmotic Induction, OI) to enhance the ARS marking method. Fish were marked in the field and immediately released in $1 \mathrm{~m}^{3}$ cages in "La Salada de Monasterio" lagoon, Chascomús, Buenos Aires, Argentina. After 73 days, clear marks were observed in the otoliths, caudal fin rays and scales with both treatments, being the intensity of the signal in the scales of OI+ARS treated fish higher. On the other hand, no marks were observed in the control group on the same structures. Approximately one year post-treatment (385 days), only marks in caudal fin rays were found clearly in OI+ARS treated fish. After this period, no significant differences in total length or weight between marked or control fish were observed and the mortality ranged between $30-40 \%$ in all cages. These results provide strong evidence for the potential applicability of this cost-effective marking technique in differentiation of wild and hatchery-produced pejerrey. The success in the caudal fin rays marking is also important because it is easy to do and does not require the sacrifice of fish.

Juvenis de pejerrey, Odontesthes bonariensis, foram expostos a Vermelho de Alizarina S (ARS) $0,1 \%$ de duas formas, sozinho ou com uma imersão anterior em $2,2 \%$ de solução salina (Indução osmótica, IO) para melhorar o método de marcação ARS. Os procedimentos foram realizados no campo e os peixes foram liberados em gaiolas (tanques-rede) de $1 \mathrm{~m}^{3}$ na lagoa "La Salada de Monasterio", Chascomús, Buenos Aires, Argentina. Após 73 dias, marcas claras foram observadas nos otólitos, raios da nadadeira caudal e escamas em ambos os tratamentos, sendo que a intensidade do sinal nas escalas de IO + ARS de peixe tratado foi superior. Por outro lado, não foram observados marcas no grupo controle sobre as mesmas estruturas. Aproximadamente um ano pós-tratamento (385 dias), apenas marcas nos raios da nadadeira caudal foram encontrados claramente nos peixes tratados com IO+ARS. Entre os peixes observados, após este período, não houve diferenças significativas no comprimento total ou peso entre o grupo controle e marcados, ademais, a mortalidade variou entre $30-40 \%$ em todas as gaiolas. Estes resultados fornecem fortes evidências e um grande potencial para aplicação desta técnica rentável de marcação que diferencia o pejerrey selvagem e o produzido em cativeiro. O sucesso na marcação dos raios da nadadeira caudal também é de grande importância, pois sua verificação é fácil e não requer o sacrifício de peixes.

Key words: Fin rays, Fish tag, Otolith, Scales.

\section{Introduction}

Pejerrey Odontesthes bonariensis (Atherinopsidae) is a brackish water species native to lakes and lagoons of Buenos Aires Province, Argentina and Rio Grande do Sul, Brazil (Dyer, 2006). Among other continental species from Argentina, the pejerrey is considered the most popular by local anglers because of its culinary value (López et al., 2001). It is also considered as a promising candidate for aquaculture (Somoza et al., 2008) as intensive culture methods had been successfully achieved in Argentina (Miranda et al., 2006; Velasco et al., 2008). As part of a long time tradition in Argentina, pejerrey larvae and juveniles are being released every year in shallow lakes and rivers of different argentine

${ }^{1}$ Laboratorio de Ictiofisiología y Acuicultura. Instituto de Investigaciones Biotecnológicas-Instituto Tecnológico de Chascomús, IIBINTECH (CONICET-UNSAM).da.campanella@gmail.com (DC); angiegarriz@intech.gov.ar (AG); somoza@intech.gov.ar (GMS); lmiranda@intech.gov.ar(LAM).

${ }^{2}$ Laboratorio de Ecología y Producción pesquera. Instituto de Investigaciones Biotecnológicas-Instituto Tecnológico de Chascomús (CONICET-UNSAM). colautti@intech.gov.ar (DCC). 
provinces (Velasco et al., 2008). Nevertheless no evaluation of the success of this practice had been ever performed.

Several methods have been developed with the common goal of stock identification and/or discrimination from wild populations including the use of tags, mark-recapture, morphology of scales or otoliths, and thermal and chemical marking (Campana \& Neilson 1985; Begg \& Waldman, 1999; Crook et al., 2007). Among these methods, chemical immersion of fish in a solution that contains a fluorescent dye has been used to mark internal calcified structures, such as otoliths (Brooks et al., 1994; Skov et al., 2001; van der Walt \& Forager 2003). Similar procedures have also resulted in the obtention of external marks, which allowed for a non-invasive detection (Mohler, 2003; Bashey, 2004; Negus \& Tureson, 2004). The most commonly used were oxytetracycline (OTC), hydrochloride, calcein, alizarin complexone (AC) and alizarin red S (ARS). However, calcein, ARS and AC performed better than other chemicals because: marks can be detected and read clearly, the effect over survival rates was proven to be less negative, and all can be used in salt water (Tsukamoto et al., 1989; Van der Walt \& Faragher, 2003; Taylor et al., 2005; Baer \& Rösch, 2008; Liu et al., 2009). Even though previously performed experiments using calcein have obtained clear and long-lasting marks, this chemical compound is expensive and was found to be toxic when fishes were exposed to it for long periods of time (Brooks et al., 1994; Bumguardner \& King, 1996; Frenkel et al., 2002). On the other hand, the use of ARS has been proven to be successful in marking fish at high scale (mass-marking) and it provides an alternative at only a fraction of the cost of the calcein and AC markers (Blom et al., 1994; Nagiec et al., 1995; Lagardere et al., 2000). Results from different studies that used ARS have shown that the compound produces highly readable marks for long periods of time (up to 842 days) in laboratory reared individuals (Crook et al., 2007).

The development of the 'osmotic induction' (OI) technique for fish marking with calcein has made possible to mark thousands of fish in less than 10 minutes (Mohler, 2003). Also, ARS has been utilized as a less expensive alternative to calcein for the OI, and results had shown the obtention of clear visible external marks after 9 months in the golden perch Macquaria ambigua (Crook et al., 2007).

In this context, the main objective of this study was to develop a quick and efficient protocol for administering ARS in pejerrey, in order to produce visible fluorescent marks and optimize this technique using a previous osmotic induction. The results obtained will be useful for the identification of captive raised juveniles stocks to be then released in water bodies.

\section{Material and Methods}

Experimental fish and immersion marking. On July $8^{\text {th }}$ of 2009,90 juveniles (total length $11 \pm 0.2 \mathrm{~cm}$; weight $7 \pm 0.45 \mathrm{~g}$ ) were selected from a stock of captive pejerrey from IIBINTECH aquaculture facilities reared following Colautti et al.,
(2010) in the "La Salada de Monasterio" lagoon (35.8331S., 57.8871 W), Chascomús, Buenos Aires, Argentina. The marking procedures were performed in situ, on a boat, using plastic containers for immersion and rinsing purposes. Fish were divided in three groups of 30 individuals and immersed in: A) ARS solution $0.1 \%$ for $10 \mathrm{~min}$; B) Osmotic shock solution of $2.2 \%$ of salinity for 10 minutes and a posterior immersion in $0,1 \%$ ARS solution for $10 \mathrm{~min}$; and C) Water from the lagoon ( $0.2 \%$ of salinity) for $10 \mathrm{~min}$ (control group) at approximately $15^{\circ} \mathrm{C}$. All the solutions were prepared with water from the lagoon and after treatments all fish were rinsed with the same water and released in cages of $1 \mathrm{~m}^{3}$ that were already set up in the lagoon. During approximately one year, fish from each cage were sampled in order to verify the presence of fluorescent marks as well. Optimal ARS dosages and exposure times were established during preliminary assays, where increasing ARS concentrations led to an increase in mortality, and decreasing ARS concentrations produced no mark in any structure.

Sampling and mark analyses. All the structures were analyzed inmediately after the obtention including the sagitta otolith (Fig. 1a), scales (Fig.1b) from the lateral flank of the body (scales were extracted from right sub-ocular region), and caudal fin rays (Fig. 1c). The criterion used to choose the sagitta as the optimal pair of ear bones was its larger size compared to the lapilli and asterisci, which facilitated the extraction (Campana \& Neilson, 1985). The otoliths were all freed from adherent tissues and rinsed with water. All samples were observed directly without resin and polishing (Liu et al., 2009). After removed, pictures of the structures were taken in a darkened room using a fluorescence microscope (Nikon Eclipse E600- G-2E/C TRITC Filter) attached to a digital camera (Nikon Digital Sight DS-U2). All photographs were obtained using the same magnification and exposure time. To assess the intensity of the ARS marks with and without osmotic induction a blind test was performed where the reader did not know the origin of the samples. At least three fish for each treatment and time period were analyzed. At the end of the experiment, growth and survival among the control and treatment groups were compared using ANOVA test.

\section{Results}

During the initial minutes of the marking procedures, pejerrey juveniles seemed to have lost equilibrium and were slowly floating towards the water surface. A few minutes later, all individuals showed signs of recovery, such as normal swimming behavior near the surface and no mortality was observed.

After 73 days post-treatment, clear marks were observed for both marking procedures, in otoliths (Fig. 2a-b), scales (Fig. 2c-d) and caudal fin rays (Fig. 2e-f).The intensity of the signal in scales was higher in fish marked with OI+ARS (Fig. 

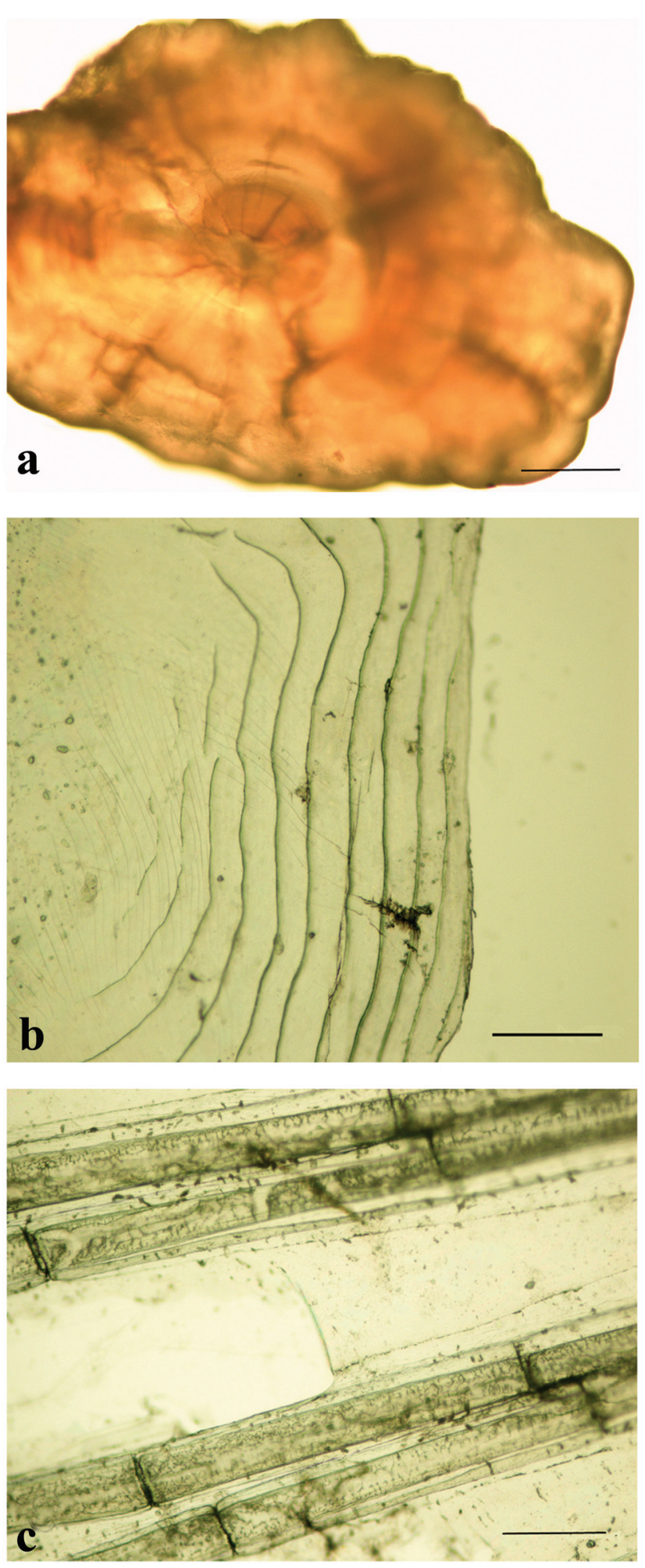

Fig. 1. Photographs of untreated pejerrey analyzed structures (30 days after experimental conditions): sagitta otolith (a), scale (b), caudal fin rays (c) under light microscope. Scale bar $=200 \mu \mathrm{m}$. 2d). After approximately one year (385 days) only marks in caudal fin rays were observed in fish treated with OI+ARS (Fig. 2g). All control fish structures and, otoliths and scales for 385 days post-immersion showed no marks under fluorescence microscope and viewed like figure $2 \mathrm{~h}$.

At the end of the analyzed period no significant differences in total length or weight between marked or control fish were observed ( $\mathrm{P}>0.05$; data not shown), and the mortality ranged between $30-40 \%$ in all cages.

\section{Discussion}

The pejerrey swimming behavior observed during the marking process (lost equilibrium and floated immediately to the surface) was also reported for the golden perch subjected to the same treatment (Crook et al., 2007). It is important to note that no differences in mortality and growth during the analyzed period were observed between treatment and control group.

The immersion of pejerrey juveniles in ARS or OI+ARS solutions resulted in a $100 \%$ marking success after 73 days post-treatment. Despite variations in the quality and lasting of the marks, fluorescent signals were detected in both treatments and all the structures analyzed. These findings are in agreement with several studies that showed ARS effectiveness for immersion marking, as well as its potential in biological research and evaluation of stock enhancement programs (Bashey, 2004; Baer \& Rösch, 2008; Crook et al., 2007; Liu et al., 2009).

It is important to note that no autofluorescence was observed in the structures analyzed, and marked and unmarked fish were easily distinguishable. Similar observations were reported by Bashey (2004) in juvenile guppies Poecilia reticulata and by Crook et al (2007) in golden perch marking with ARS. None of the treatments have affected pejerrey growth and survival (Colautti et al., 2010), and these results are in agreement with data reported by Liu et al (2009) for the Japanese flounder.

A higher signal intensity was found in the scales of OI+ARS treated fish after 73 days post-treatment, and only marks in caudal fin rays were found after more than 1 year post-immersion in OI+ARS. These results showed that the osmotic induction before immersion in ARS produces higher intensity marks than the direct immersion in ARS as it was previously reported in golden perch by Crook et al (2007) and using calcein in Atlantic salmon (Mohler, 2003). The success of this technique lies on the concept of the osmotic potential, as fish are exposed to a hyperosmotic environment when compared to the internal individual tissues and fluids. Hypothetically, this osmotic difference results in water loss from body fluids and then, when exposed to the marking solution, a fast uptake of the compound as some sort of replacement (Conte, 1969). Afterwards, the ARS binds to the calcium in fin rays, scales and otoliths. 

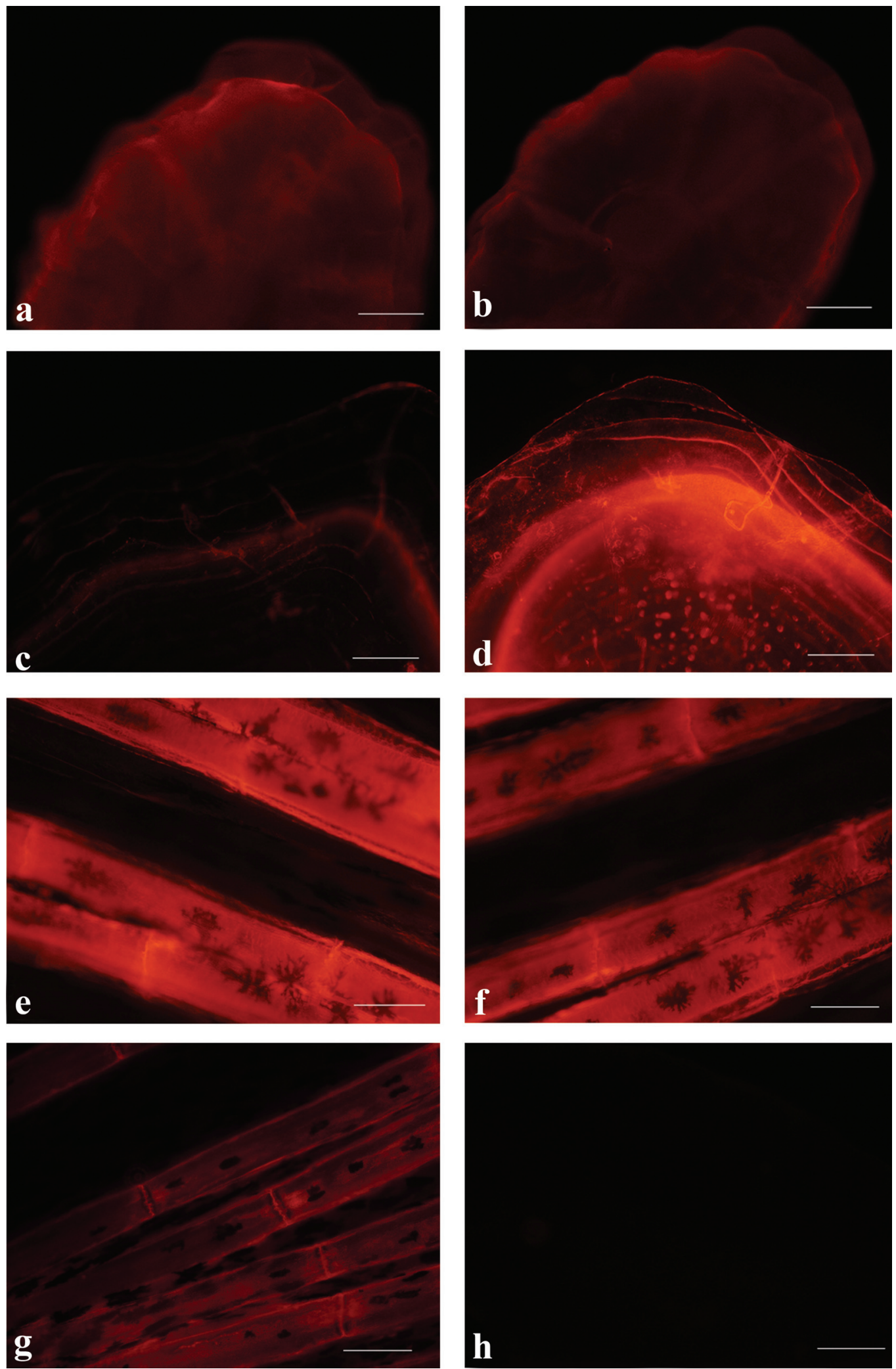

Fig. 2. After 73 days post-treatment, clear marks were observed for both marking procedures, in otoliths (Figs. 2a, b), scales (Figs. 2c, d) and caudal fin rays (Figs. 2e, f). The intensity of the signal in scales was higher in fish marked with OI+ARS (Fig. 2d). After 385 days, only marks in caudal fin rays were observed in fish treated with OI+ARS (Fig 2g). All control fish structures and, otoliths and scales for 385 days post- immersion showed no marks under fluorescence microscope (Fig. 2h). a, c, e: ARS treatment; b, d, f, g: OI+ARS treatment. Scale bar $=200 \mu \mathrm{m}$. 
What is important to stress is that, as shown in this study, otolith marks could be easily observed without any preparation of the sample such as the use of glycerin, or polishing the earbone surface (Vigliola, 1997; Taylor et al., 2005). Therefore, the amount of time required in order to verify the existence of the mark has been greatly reduced. However, when it comes to the verification of the marks, otoliths still require the sacrifice of the individuals. But as the OI+ARS treatment resulted in clear marks in the scales and caudal fin rays, marked fish can be easily detected without killing them.

Marking of fish by immersion requires a trade-off among cost, compound concentration, immersion time, salinity, mortality, growing condition and retention time to produce the best mark (Taylor et al., 2005). Also, it is important to assess which is the best life stage to perform the marking immersion, as chemical dyes form complexes with calcium and these were deposited in the bone as the fish grows (Eckmann, 2003).

To the best of our understanding, this study has shown for the first time that Odontesthes bonariensis juveniles can successfully retain ARS mark up to one year after the marking immersion. Future research must also be conducted working with earlier pejerrey stages, because only in the last year approximately 25 million of pejerrey embryos, larvae and juveniles were released in Argentinean water bodies by government hatcheries without any evaluation of the stock enhancement effectiveness. Even though the methods reported will require further research and testing, osmotic induction marking with ARS has considerable potential as a low cost, effective and practical technique for mass marking juvenile pejerrey.

\section{Acknowledgments}

This work was supported by grants to Leandro Andrés Miranda (ANPCyT PICT 2007-1181), Dario César Colautti (ANPCyT PICT 38352-07) and an undergraduate training fellowship awarded by Comisión de Investigaciones Científicas of Buenos Aires province to Daniela Campanella.

\section{Literature Cited}

Baer, J. \& R. Rösch. 2008. Mass-marking of brown trout (Salmo trutta L.) larvae by alizarin: method and evaluation of stocking. Journal of Applied Ichthyology, 24: 44-49.

Bashey, F. 2004. A comparison of the suitability of alizarin red S and calcein for inducing a nonlethally detectable mark in juvenile guppies. Trans American Fisheries Society, 133: 1516-1523.

Begg, G. A. \& J. R. Waldman. 1999. An holistic approach to fish stock identifcation Fisheries Research, 43: 35-44.

Blom, G., J. T. Nørdeide, T. Svasand \& A. Borge. 1994. Application of two fluorescent chemicals, alizarin complexone and alizarin red S, to mark otoliths of Atlantic cod, Gadus morhua L. Aquatic Fisheries Management, 25: 229-243.
Brooks, R. C., R. C. Heidinger \& C. C. Kohler. 1994. Mass-marking otoliths of larval and juvenile walleyes by immersion in oxytetracycline, calcein, or calcein blue. North American Journal of Fisheries Management, 14: 143-150.

Bumguardner, B. W. \& T. L. King. 1996. Toxicity of oxytetracycline and calcein to juvenile striped bass. Trans American Fisheries Society, 125: 1443-1445.

Campana, S. E. \& J. D. Neilson. 1985. Microstructure of fish otoliths. Canadian Journal of Fisheries Aquatic Sciences, 42: 1014-1032.

Colautti, D. C., J. R. Garcia, L. Balboni \& C. R. M. Baigún. 2010. Extensive cage culture of pejerrey (Odontesthes bonariensis) in a shallow pampean lake (Argentina). Aquaulture Research, 41: 376-384.

Conte, F. P. 1969. Salt secretion. Pp. 241-292. In: Hoar, W. S. \& D. J. Randall (Eds.). Fish Physiology. New York, Academic Press, $465 \mathrm{p}$.

Crook, D. A., D. O. Mahony, B. M. Gillanders, A. R. Munro \& A. C. Sanger. 2007. Production of external fluorescent marks on Golden Perch fingerlings through osmotic induction marking with Alizarin Red S. North American Journal of Fisheries Management, 27: 670-675.

Dyer, B. S. 2006. Systematic revision of the South American silversides (Teleostei, Atheriniformes). Biocell, 30:69-88.

Eckmann, R. 2003. Alizarin marking of whitefish, Coregonus lavaretus otoliths during egg incubation. Fisheries Management Ecology, 10: 233-239.

Frenkel, V., G. Kindschi \& Y. Zohar. 2002. Noninvasive, mass marking of fish by immersion in calcein: evaluation of fish size and ultrasound exposure on mark endurance. Aquaculture, 214: 169-183

Lagardere, F., K. Thibaudeau \& M. L. Begout Anras. 2000. Feasibility of otolith markings in large juvenile turbot, Scophthalmus maximus, using immersion in alizarin-red S solutions. Journal of Marine Science, 57: 1175-1181.

Liu, Q., X. M. Zhang, P. D. Zhang \& S. A. Nwafili. 2009. The use of alizarin red $\mathrm{S}$ and alizarin complexone for immersion marking Japanese flounder Paralichthys olivaceus (T.). Fisheries Research, 98: 67-74.

López, H. L., C. R. M. Baigún, J. M. Iwaskiw, R. L. Delfino \& O. H. Padín. 2001. La cuenca del Salado: Uso y posibilidades de sus recursos pesqueros. La Plata, Ed. Univ. La Plata,76p.

Miranda, L. A., G. E. Berasain, C. M. Velasco, Y. Shirojo \& G. M. Somoza. 2006. Natural spawning and intensive culture of pejerrey Odontesthes bonariensis juveniles. Biocell, 30: 89-95.

Mohler, J. W. 2003. Producing fluorescent marks on Atlantic salmon fin rays and scales with calcein via osmotic induction. North American Journal of Fisheries Management, 23: 1108-1113.

Nagiec, M. P., K. Czerkies, A. Goryczko, E. Witkowski \& E. Murawska. 1995. Mass-marking of grayling, Thymallus thymallus (L.), larvae by flourochrome tagging of otoliths. Fisheries Management Ecology, 2:185-195.

Negus, M. T. \& F. T. Tureson. 2004. Retention and nonlethal external detection of calcein marks in rainbow trout and Chinook salmon. North American of Fisheries Management, 24: 741-747.

Somoza, G. M., L. A. Miranda, G. E. Berasain, D. C. Colautti, M. Remes-Lenicov \& C. A. Strüssmann. 2008. Historical aspects, current status, and prospects of pejerrey aquaculture in South America. Aquaculture Research, 9:784-793. 
Skov, C., P. Grønkjær \& C. Nielsen. 2001. Marking pike fry otoliths with alizarin complexone and strontium: an evaluation of methods. Journal of Fish Biology, 59:745-750.

Taylor, M. D., D. S. Fielder \& I. M. Suthers. 2005. Batch marking of otoliths and fin spines to assess the stock enhancement of Argyrosomus japonicus. Journal of Fish Biology, 66: 11491162.

Tsukamoto, K., H. Kuwada, J. Hirokawa, M. Oya, S. Sekiya, H. Fujimoto \& K. Imazumi. 1989. Size dependent mortality of red sea bream, Pagrus major, juveniles released with fluorescent otolithtags in New Bay, Japan. Journal of Fish Biology, 35: 59-69.

van der Walt, B. \& R. A. Faragher. 2003. Otolith marking of rainbow trout fry by immersion in low concentrations of alizarin complexone. North American Journal of Fisheries Management, 23: $141-148$.

Velasco, C. A, G. E. Berasain \& M. Ohashi. 2008. Producción intensiva de juveniles de pejerrey (Odontesthes bonariensis). Biología Acuática, 24: 53-58.

Vigliola, L. 1997.Validation of daily increment formation in otoliths for three Diplodus species in the Mediterranean sea. Journal of Fish Biology, 51: 349-360.

Submitted August 17, 2012

Accepted November 20, 2012 by Francisco G. Araújo

Published March 31, 2013 